\title{
LERNAEOCERA OBTUSA N.SP., A HITHERTO UNDESCRIBED PARASITE OF THE HADDOCK (GADUS AEGLEFINUS L.)
}

\author{
By Z. Kabata
}

The Marine Laboratory, Aberdeen

(Text-figs. I-6)

The present genus Lernaeocera comprises seven species. Four of them are known to occur on the western European seaboard. They are: L. branchialis (Linnaeus, 1767) L. lusci Basset-Smith, 1896, L. minuta T. Scott, 1900, and L. brevicollis Schuurmans Stekhoven, I935. The three non-European species have been based on isolated specimens from Chile (L. rigida Krøyer, I863), New Zealand (L. lotellae Thomson, 1889) and Antarctica (L. godfroyi Quidor, 1912). All are parasitic on fish.

The final hosts infested by the members of this genus can be divided into two groups: the 'inshore' group, comprising those fishes which visit the coastal waters at some stage of their lives and which are exposed to infestation by a parasite reproducing in that zone only; and the 'offshore' group, comprising those which do not visit the coastal waters at any stage and which can be infested only by a parasite with a totally offshore life cycle. One of the common hosts, the Haddock, Gadus aeglefinus L., can be included in both groups, as its small coastal populations can be treated, for our purposes, separately from its main offshore stocks. Out of $3 \mathrm{I}$ recorded hosts of the European species 27 belong to the inshore group. All the common final hosts, with the exception of the offshore haddock, and all the known intermediate hosts also belong to this group. The present genus Lernaeocera might be regarded, therefore, as essentially coastal in character.

L. branchialis, as it has been presented in the previous literature, stands out as conspicuously unusual, when considered against the background of its own genus. It appears to be the only species with the common hosts both in the inshore and the offshore group. In the former it is known to infect commonly such hosts as the Cod (Gadus callarias L.) and the Whiting (G. merlangus L.), and in the latter-where no intermediate host has been recordedthe haddock. Of all the other species of the genus only one, Lernaeocera lusci, has been recorded from offshore hosts but none of these can be regarded as common. Both L. lusci and Lernaeocera found on haddock resemble each other in the shape of the body, although the latter attains larger sizes. Both also differ in shape from the L. branchialis found on the hosts of the inshore group. 
In his study of $L$. branchialis the attention of the present author was drawn to this difference between this species and the remaining members of the genus, and also to the differences within the species itself. It seemed that these differences could be explained if it could be proved that the name L. branchialis has been used hitherto to cover two distinct species, one from the whiting and the cod and the other from the haddock. Closer investigation has shown that this, indeed, is so. In this paper the existence of the new species is demonstrated. The evidence is to be found in the geographical distribution, specificity and morphology of the adult male and female and in the mode of attachment to the final host.

\section{DISTRIBUTION}

Parasites of the genus Lernaeocera can become endemic only in the areas inhabited by a suitable intermediate host and their distribution cannot be considered without reference to their intermediate hosts. These are known only for L. branchialis, the common intermediate host of which appears to be the Flounder, Platichthys flesus (L.) (A. Scott, 190I ; Sproston, 194I). Gouillart (1937) and Stekhoven (1936) also list Plaice, Pleuronectes platessa L., Gouillart (1937) lists Turbot, Scophthalmus maximus (L.), while Oorde de Lint \& Stekhoven (1936) mention 'other pleuronectids' without naming any. Shulman \& Shulman-Albova (1953) found that the Arctic Flounder, Liopsetta glacialis (Pallas) and the Lumpsucker, Cyclopterus lumpus L., werebeside the flounder-common intermediate hosts of $L$. branchialis in the White Sea, and they reached the conclusion that the reproductive cycle of this parasite is exclusively coastal in character. Gouillart (1937) also mentions C. lumpus, but regards the larvae found on it as being specifically distinct from L. branchialis.

The distribution of the fish infested exclusively in the coastal area can be expected to present a gradient with the incidence decreasing as the distance from the shore increases. Such a gradient has been found by Sproston \& Hartley (194I) for Whiting and Pollack, Gadus pollachius L., infested with L. branchialis, and by Templeman (1953) for the cod of the north-west Atlantic infested with the same parasite. The present author studied the distribution of the infested whiting and haddock by examining the commercial catches landed in the Aberdeen Fish Market and the catches made by the research vessels of the Marine Laboratory, Aberdeen. Over 2000 whiting and 30,000 haddock were examined. It became apparent that the two species differ remarkably in the distribution of their infested individuals. The incidence of Lernaeocera in whiting fully conformed with the expected pattern. Table I shows the results of the examination of 407 whiting in August 1956. The incidence of infestation decreased with the distance from the shore and also markedly with the size of the fish. Examination of 474 whiting in the 
Firth of Forth in November 1956 showed that the incidence of Lernaeocera tended to decrease eastwards, i.e. towards the mouth of the Firth, and to cease in the waters within the area Io miles west of May Island. Of the I300 whiting caught commercially only three were found to be infested. All three were taken a considerable distance from the shore, but constituted such an insignificant proportion of the fish examined that they can be disregarded in any consideration of the distribution.

Infested cod can be found over the entire area of the northern North Sea, but only in small numbers. Of 832 cod examined during the second half of I955 only $3 \mathrm{I}$, or $3.7 \%$ were found to be infested. No distinct pattern of distribution has emerged, but it seemed possible that the fishes were infested inshore and migrated outwards. Of the $3 \mathrm{I}$ infested individuals only four carried parasites which were not fully mature and all of these were caught no farther than 18 miles from the shore.

The distribution of the infested haddock bore no relation to the distance from the shore at all; neither did the state of the maturity of the parasites. All stages of development, including the youngest post-larval stage, the 'penella', were found at varying distances; the duration of the latter stage is estimated by Capart (1948) to be about IO-I5 days. It is difficult to imagine that haddock could frequently be infested near the coast and cover a distance of roo miles or more in the period of time during which the parasite will remain in this stage of development. The 'penella' stage was found on haddock of all sizes and ages and was not restricted to the younger and smaller individuals which one associates with the inshore waters.

These facts suggested that an intermediate host must exist in the offshore zone and that only a parasite with the reproductive cycle independent of the inshore region can be responsible for the distribution shown by the Lernaeocera-infested haddock. For this reason, in the spring of 1956 , a search was made for an intermediate host which could account for the completion of the life cycle of the Lernaeocera affecting offshore haddock. Six common species of flatfishes were investigated, from numerous localities both in- and offshore (Fig. I). The results are summarized in Table 2. Over $95 \%$ of the investigated Lemon Sole, Microstomus kitt (Walbaum), were infested with larval Lernaeocera. No other species was found to be infested. Especially noteworthy is the absence of the larvae from plaice, which is regarded by Stekhoven (I936) as one of the common intermediate hosts of $L$. branchialis. No locality shown in Fig. I was found to be free of Lernaeocera. There is no previous record of the occurrence of Lernaeocera in the lemon sole.

As a further check, the distribution of infested haddock was compared with that of lemon sole in the North Sea as determined by Rae (1939). The comparison made it clear that the incidence of the infestation of haddock was fairly closely related to the abundance of the lemon sole in this region.

The problem emerged: why is the offshore haddock infested with 
TABLE 1. DISTRIBUTION OF INFESTED WHITING, AS SHOWN BY THE FISH EXAMINED IN AUGUST 1956 BY F.R.S. EXPLORER

\begin{tabular}{|c|c|c|c|c|c|c|c|c|}
\hline Date & Locality & Position & $\begin{array}{l}\text { Distance } \\
\text { from shore } \\
\text { (miles) }\end{array}$ & $\begin{array}{l}\text { Depth } \\
\text { (fm.) }\end{array}$ & $\begin{array}{r}\text { Size } \\
(\mathrm{cm} .)\end{array}$ & Examined & Infested & $\begin{array}{l}\text { Percentage } \\
\text { infested }\end{array}$ \\
\hline I2. viii. & Off Cruden Scaurs & $57^{\circ} 20_{2}^{\prime}{ }^{\prime}$ N., $I^{\circ} 48^{\prime} \mathrm{W}$. & ca. 4 & 35 & $2 I-23$ & 70 & 6 & $8 \cdot 6$ \\
\hline \multirow[t]{3}{*}{ I2. viii. } & Edge of Buchan Deeps & $57^{\circ} 24^{\prime}$ N., $\quad I^{\circ} 28^{\prime}$ W. & ca. I4 & 42 & $<25$ & II5 & 5 & $4 \cdot 3$ \\
\hline & & & & & $>25$ & 222 & I & 0.4 \\
\hline & & & & & & tal 337 & 6 & $\mathrm{I} \cdot 8$ \\
\hline
\end{tabular}

TABLE 2. LIST OF FLATFISHES EXAMINED FOR THE INCIDENCE OF LARVAL LERNAEOCERA

Percentage

Infested infested

Lemon sole, Microstomus kitt (Walbaum)

Plaice, Pleuronectes platessa L.

Witch, Glyptocephalus cynoglossus (L.)

Megrim, Lepidorhombus whiff-iagonis (Walbaum)

Dab, Limanda limanda (L.)

Long rough dab, Drepanopsetta platessoides Gill

$$
222
$$

59

96

219
289

$\begin{array}{ll}211 & 95 \circ \\ \text { Z } & \text { - } \\ \text { - } & \text { - }\end{array}$


Lernaeocera, while the offshore whiting is free from infestation? The differences in behaviour and the habitat between the two species provide no answer. While they could explain lower incidence of infestation of whiting, they cannot account for its total absence in this fish. It is apparent therefore that there is only one other possible explanation-the parasite which infests haddock in the open sea is specifically distinct from the one which lives inshore and infests other gadoid species.

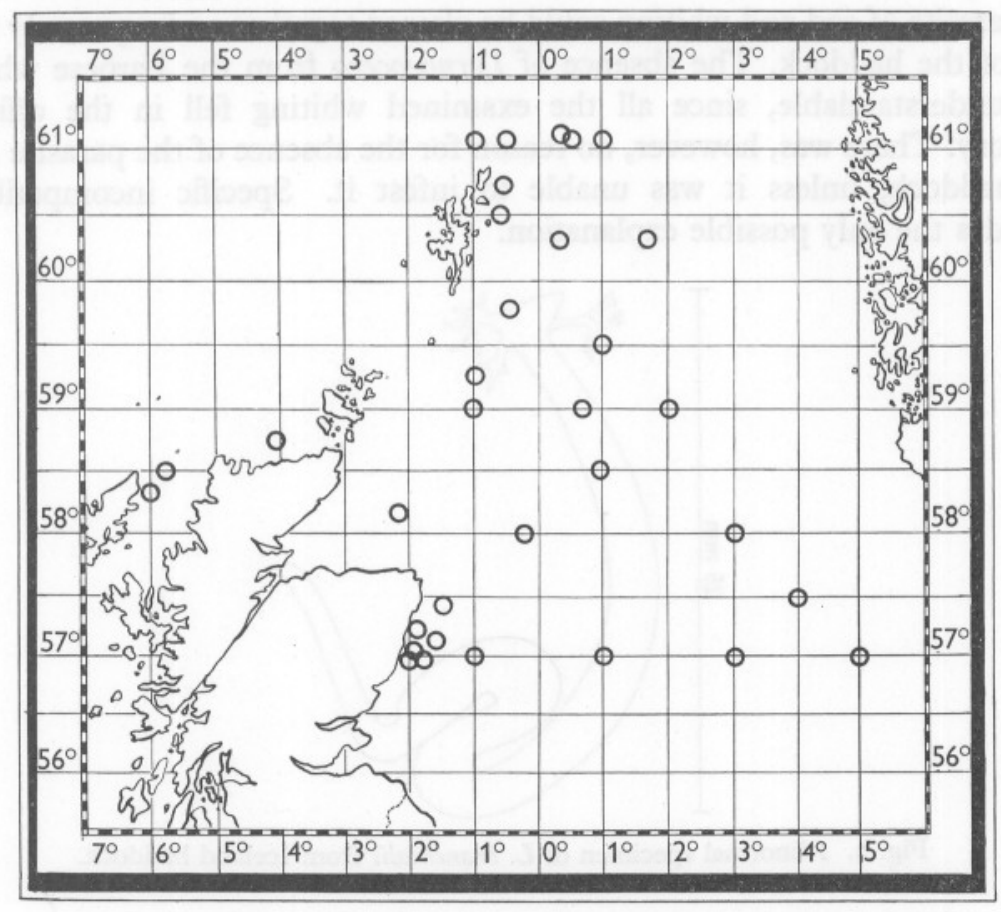

Fig. I. Localities in which lemon sole infested with Lernaeocera have been found.

Investigations in Faröe waters in October 1955 showed, quite surprisingly, the complete absence of Lernaeocera from the haddock of that area. The numbers of fish examined on that occasion were 2450 haddock, 477 whiting and 155 cod.

Only the cod was found to be infested by Lernaeocera (6 individuals, $5 \%$ of the total examined). One of the infested cod carried a 'penella' stage of the parasite. Three were too young to have been migrants from elsewhere. Similar results have been obtained in October 1956, when there were examined I 434 haddock, I23 whiting and I74 cod.

This time $8 \%$ of the cod examined were found to be infested, and some of 
the $I_{5}$ infested individuals were again too young to be anything but local fish. Only one haddock was infested with a $15 \mathrm{~mm}$ long 'penella' stage.

These results show that Lernaeocera is endemic in the Faröe waters. It has presumably spread into that area from the south, possibly carried by cod, and has become established there in presence of an intermediate host. Haddock, on the other hand, do not migrate to Faröe from the North Sea. Both flounder and lemon sole are endemic in Faröe.

The patterns of the distribution of Lernaeocera in the North Sea showed that the parasite of cod and whiting could be classed together and separately from that of the haddock. The absence of Lernaeocera from the Faröese whiting was understandable, since all the examined whiting fell in the offshore category. There was, however, no reason for the absence of the parasite from the haddock, unless it was unable to infest it. Specific incompatibility provides the only possible explanation.

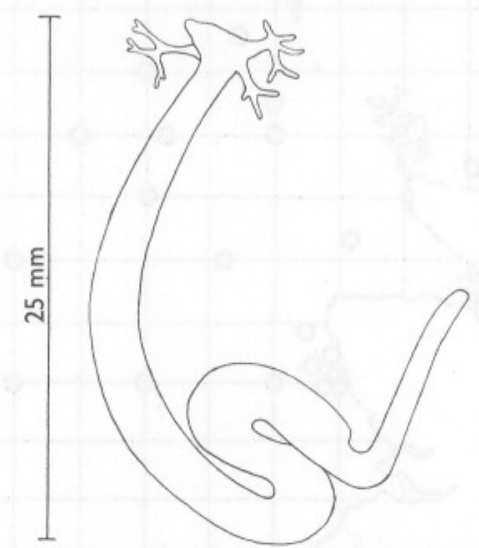

Fig. 2. Abnormal specimen of L. branchialis from Iceland haddock.

Investigations were also carried out in Iceland waters. No whiting were caught, but a sample of 250 cod and 299 haddock was examined for Lernaeocera. Of these, 23 cod of widely separated areas were infested, but only one haddock carried Lernaeocera. The parasite on the haddock was not normally developed (Fig. 2). It was implanted in the branchial arch, all three antlers were present and the length of the body, from the head to the genital flexure, was $25 \mathrm{~mm}$. The widest diameter of the body was no more than $\mathrm{I}_{2} \frac{1}{2}$ times that of the neck. No egg-strings were present. The general impression was of the retention of juvenile characteristics with simultaneous increase in size, a feature not uncommon in parasites attached to a 'wrong' host.

The geographic distribution of Lernaeocera of the cod and the whiting on the one hand and of the haddock on the other suggests that the existence of two species covered until now by the specific name branchialis is at least possible. 
It should also be mentioned that no records of the infestation of haddock with Lernaeocera in either Faröe or Iceland were found by the author in literature.

\section{MORPHOLOGY OF THE ADULT FEMALE}

The variations and irregularities of the body shape of $L$. branchialis have prompted some workers (Stekhoven, 1936; Dollfus, 1953) to regard it as a rather unreliable specific feature. It has been felt that the shape of the body might be largely determined by the species and the size of the host. The volume and the shape of the subopercular space, depending on the species of the host, and the abundance of food, depending on its size, were regarded as the main factors determining the shape and the size of the parasite's body.

A logical chain of causes and effects is, smaller host-less food for the parasite-poorer growth-smaller parasite. When, however, it is followed a step further, a conclusion will be reached that the very fact of the parasite being smaller must restore the balance between the size of the parasite and the space available for it. Also, the subopercular spaces of related hosts of equal sizes do not differ sufficiently to produce any marked differences in the shape of the body of the parasite. Consideration of hosts of the same species shows, for example, that although the parasites of small and of large whiting differ in size, and usually also in age, no differences can be observed between the shapes of their bodies.

It must be remembered that the parasite growing in the subopercular space is not enclosed by rigid and immovable walls. The opercula perform constant movements, the effect of which can be compared rather to a series of pushes than a steady pressure. The body bends in the neck region as the result of these pushes and assumes the direction of growth parallel to the longitudinal axis of the body of the host, i.e. in the direction in which the maximum of the available space can be found. Very often a perfectly developed and not at all misshapen parasite is found protruding from under the operculum of the host. The obviously cramped conditions of growth do not seem to have affected the shape of its body. The occurrence of abnormalities must be expected, but they can be taken into account and do not affect the main argument. The existence of the genetical range of variability in shape must also be considered.

The following details of the body shape have been used as specific characters in Lernaeocera by the earlier workers. (i) The shape of the antlers (crosssection: T. \& A. Scott, I913; the mode of branching: Stekhoven, 1936). (ii) The structure of the cephalothoracic appendages (2nd antennae, 2nd maxillae: Stekhoven, 1936). (iii) The shape of the trunk (various authors).

The shape of the antlers is a very unreliable character and has been regarded as such even by those who applied it as an auxiliary feature in the diagnosis of 
the species. Hardly any two parasites can be found with the identical environmental conditions for the growth of the antlers. The difference in the crosssection of the antlers can be used only to distinguish between $L$. lusci (crosssection oval) and all the other species of the genus (cross-section round).

The structure of cephalothoracic appendages, although it has been suggested as a possible distinguishing characteristic, must be used very cautiously in diagnosis of the species, since the existence of two or more species with the identical structure of these appendages is not impossible.

The shape of the antlers was not helpful in distinguishing Lernaeocera found on whiting and on haddock. The structure of the cephalic appendages in the parasites found on these species showed no appreciable differences. Attention was then focused on the shape of the main trunk of the body, which has never been a subject of careful and detailed study. Most of the existing descriptions of the shape of the trunk can be applied to more than one species of Lernaeocera. It must be remembered also that most of the descriptive work on the structure of L. branchialis is based on specimens found on cod and whiting. Very few, if any, Lernaeocera from haddock were thoroughly examined. Of 32 specimens examined by Wilson (1917) none was from haddock, while Stekhoven (1936) had only two parasites from that host from the total of 143 specimens at his disposal.

In the course of this work more than 4000 fully developed specimens of Lernaeocera from haddock have been examined. It has not been possible to examine them all thoroughly, but observations have been made on the average shape of the parasite's body. It became obvious that a definite difference existed between the average shapes of Lernaeocera from whiting and from haddock. With one exception (Blainville, I822) the whiting Lernaeocera corresponds with all the illustrations made by earlier workers, but the haddock Lernaeocera differs from them in a number of easily observable points. When the study of distribution suggested the possibility of the existence of two species, these apparent morphological differences were investigated more closely on the samples of over 60 specimens of mature Lernaeocera from both whiting and haddock. The following details of structure were examined: (i) the differences between the angle of flexure of genital segments; (ii) the relations between the thickness of the neck and the main trunk; (ii) the differences of the body shape in the neck and trunk junction area.

Genital flexure. The angles of flexure of the genital segment were measured with a Starret protractor. The results obtained are graphically presented in Fig. 3, which shows a definite difference between the two parasites. More details are given in Table 3. The parasite found on whiting had usually a sharply flexed abdomen. Out of 63 individuals examined only three had the angle of flexure wider than $90^{\circ}$ and the average value was $66^{\circ}$. The angle of flexure in the haddock parasite was decidedly more obtuse and averaged $99^{\circ}$, 
with values up to $140^{\circ}$ being found. The ranges overlapped to the extent of $18.8 \%$.

A sample of Lernaeocera collected from Iceland cod in September 1956 was also examined. Although there were somewhat more specimens over $90^{\circ}$ than in the parasite of whiting, the cod Lernaeocera certainly resembled that

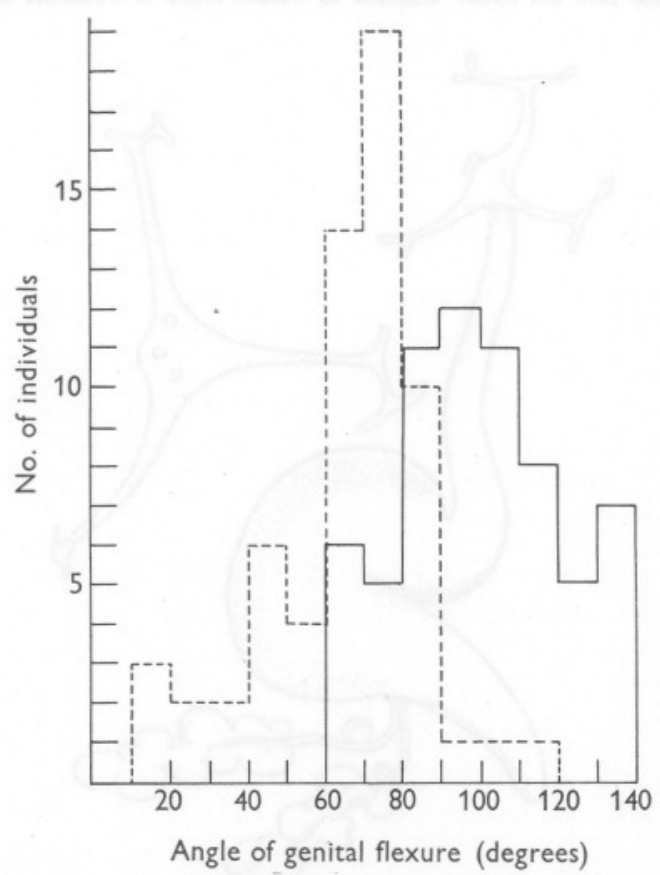

Fig. 3. Distribution of values for angle of genital flexure of Lernaeocera. Solid line, parasite of haddock; interrupted line, parasite of whiting.

TABLE 3. THE ANGLES OF GENITAL FLEXURES OF LERNAEOCERA FROM DIFFERENT HOSTS

\begin{tabular}{|c|c|c|c|c|c|}
\hline Host species & $\begin{array}{c}\text { No. of } \\
\text { parasites } \\
\text { examined }\end{array}$ & Range & Mean & $\begin{array}{l}\text { More } \\
\text { than } \\
90^{\circ}\end{array}$ & $\begin{array}{l}\text { Less } \\
\text { than } \\
90^{\circ}\end{array}$ \\
\hline $\begin{array}{l}\text { Haddock } \\
\text { Whiting } \\
\text { Cod (Iceland) }\end{array}$ & $\begin{array}{l}65 \\
63 \\
25\end{array}$ & $\begin{array}{l}61^{\circ} 30^{\prime}-139^{\circ} 45^{\prime} \\
17^{\circ} 45^{\prime}-110^{\circ} 40^{\prime} \\
21^{\circ} 10^{\prime}-125^{\circ} 10^{\prime}\end{array}$ & $\begin{array}{l}99^{\circ} \\
66^{\circ} \\
70^{\circ}\end{array}$ & $\begin{array}{r}44 \\
3 \\
6\end{array}$ & $\begin{array}{l}21 \\
60 \\
19\end{array}$ \\
\hline
\end{tabular}

from the whiting more strongly than it did that from haddock. Its mean value for the genital flexure was only $4^{\circ}$ larger than that of the whiting's parasite, whereas in the haddock Lernaeocera it was as much as $33^{\circ}$ larger. This feature, as the patterns of distribution and the mode of infestation, tends to draw the dividing line between the parasites of cod and whiting on one side and that of the haddock on the other. 
The main trunk of the average haddock Lernaeocera bears very close resemblance to that of $L$. lusci, and it would not be surprising if at least some of the records of the latter species from haddock and other hosts of the offshore group proved attributable to the smaller individuals of normal haddock Lernaeocera. This surmise removes the difficulty of assuming an 'open sea' reproductive cycle for $L$. lusci which is otherwise a coastal species.

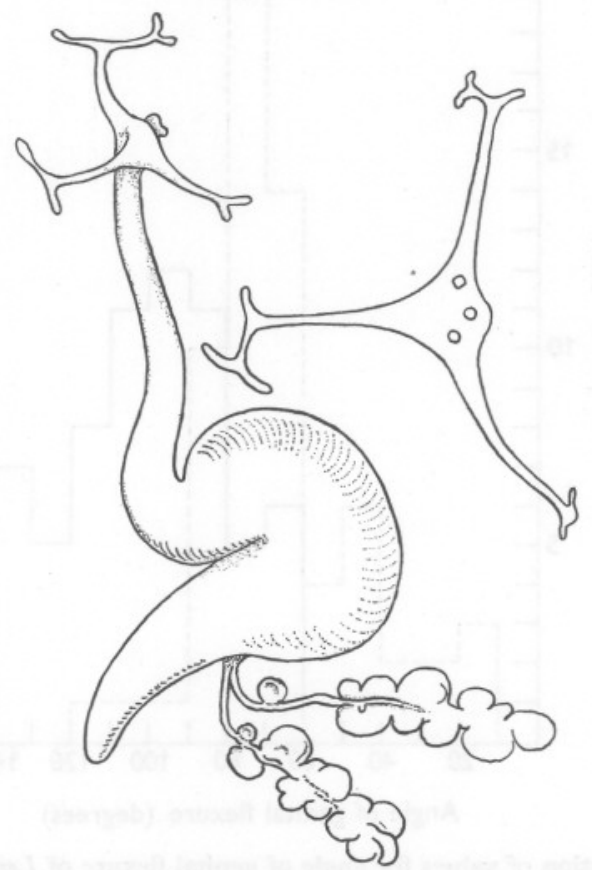

Fig. 4. (Redrawn from Blainville.) Lernaeocera showing typical features of the haddock parasite.

It is interesting to note that Blainville (I822), who states in his paper that L. branchialis occurs on Gadus aeglefinus and G. barbatus, ${ }^{1}$ illustrated in his drawing of that parasite a body of such typically 'haddock type' that no doubt can be held as to which species was the host of that particular specimen (Fig. 4).

Relation of neck and trunk diameters. Another pronounced difference between the parasites is the relation between the diameters of the neck and trunk. There can be little doubt as to the validity of this feature in the specific diagnosis. The length of the neck may well be dependent on environmental influences, but these can in no way account for marked differences in its thickness and its relationship to the thickness of the main trunk.

1 According the Günther ( 1862 ) the name Gadus barbatus is applied to (a) younger stage of European Cod, (b) Greenland species, G. ogac, (c) G. luscus. 
A quantitative check of these differences has been made on 40 individuals from both whiting and haddock and the results are summarized below:

$\begin{array}{llc} & \text { Range } & \text { Mean } \\ \text { Haddock } & 0.35-0.72 & 0.50 \\ \text { Whiting } & 0.23-0.44 & 0.31\end{array}$

The measurements show that the neck of the haddock parasite is relatively much thicker than that of the whiting, although here again the ratios exhibit a range of variation and some overlap.

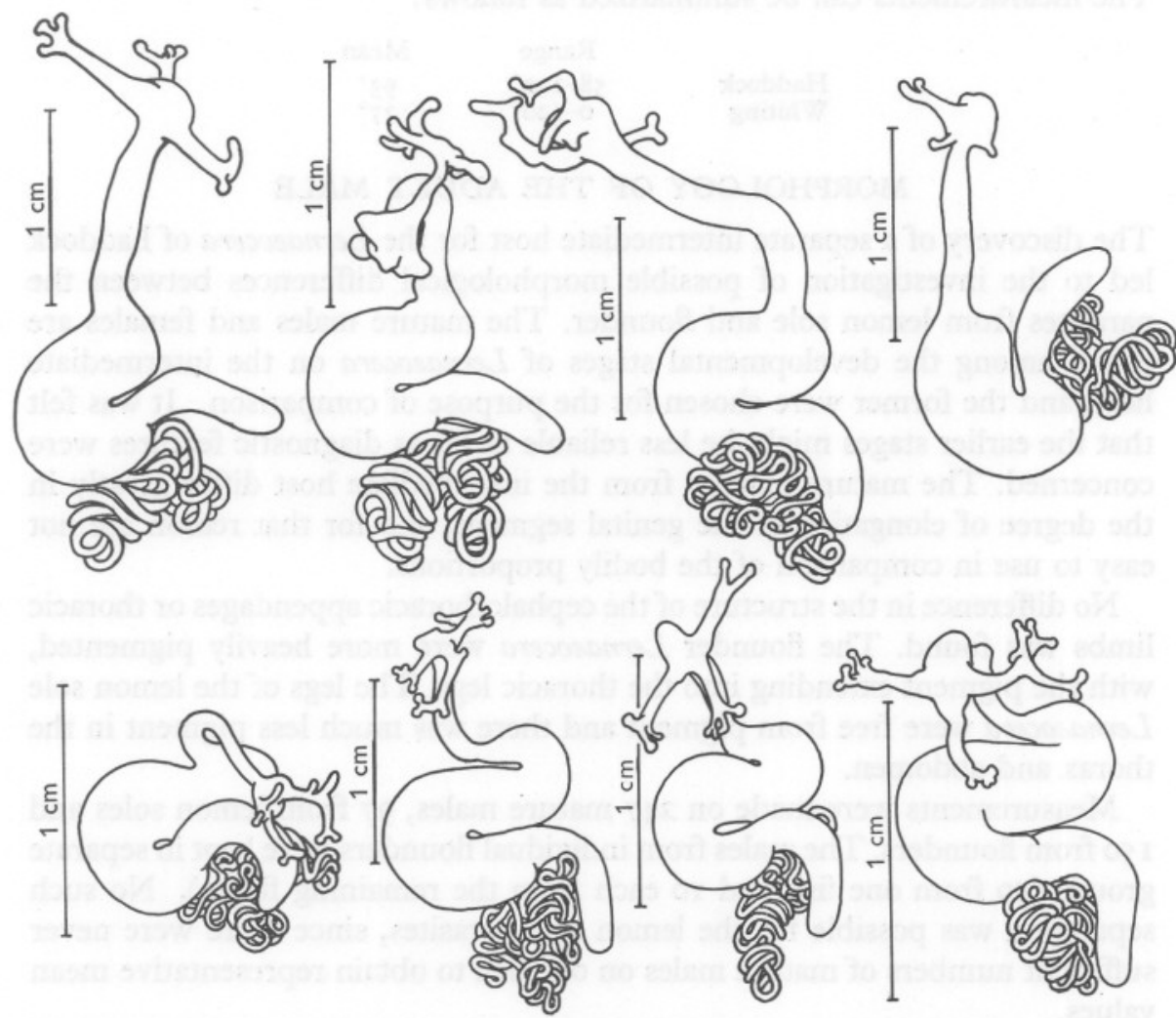

Fig. 5. Morphological differences between $L$. branchialis and L. obtusa. Upper, L. obtusa from haddock; lower, L. branchialis from whiting. Not to scale, but a line indicating $\mathrm{I} \mathrm{cm}$ is drawn beside each specimen.

Shape of neck and trunk junction. Fig. 5 illustrates the third feature distinguishing between the Lernaeocera of whiting and haddock. It will be observed that the way in which the neck merges into the trunk is different in both animals. In the parasite of whiting the transition is sudden and well marked. The thin neck abruptly dilates into the trunk with the formation of a prominent bulge at the point of junction of the two parts. The prominence 
of the bulge is accentuated by the thinness of the neck. In the parasite of haddock the transition from the neck into the trunk is more gradual and there is usually no bulge present, or only a slight one. The formation of the bulge in the parasite of whiting might be caused by, and is usually associated with, the sharp flexure in that area. The angle between the neck and the anterior part of the trunk is very acute in Lernaeocera of whiting and far less acute in that of the haddock. To check this difference quantitatively the angles of flexure were measured in over 40 parasites of haddock and over 50 of whiting. The measurements can be summarized as follows:

$\begin{array}{lrc} & \text { Range } & \text { Mean } \\ \text { Haddock } & 58-142^{\circ} & 93^{\circ} \\ \text { Whiting } & 0-120^{\circ} & 27^{\circ}\end{array}$

\section{MORPHOLOGY OF THE ADULT MALE}

The discovery of a separate intermediate host for the Lernaeocera of haddock led to the investigation of possible morphological differences between the parasites from lemon sole and flounder. The mature males and females are found among the developmental stages of Lernaeocera on the intermediate host, and the former were chosen for the purpose of comparison. It was felt that the earlier stages might be less reliable as far as diagnostic features were concerned. The mature females from the intermediate host differ greatly in the degree of elongation of the genital segment, and for that reason are not easy to use in comparison of the bodily proportions.

No difference in the structure of the cephalothoracic appendages or thoracic limbs was found. The flounder Lernaeocera were more heavily pigmented, with the pigment extending into the thoracic legs. The legs of the lemon sole Lernaeocera were free from pigment and there was much less pigment in the thorax and abdomen.

Measurements were made on 247 mature males, 97 from lemon soles and I 50 from flounders. The males from individual flounders were kept in separate groups ( 50 from one fish and ro each from the remaining fishes). No such separation was possible for the lemon sole parasites, since there were never sufficient numbers of mature males on one fish to obtain representative mean values.

Two separate series of measurements were made. The first series contained measurements of 47 males from lemon soles and roo from flounders. For this series the following measurements were taken on each individual: (i) total length, (ii) cephalothorax length, (iii) total length minus cephalothorax, (iv) cephalothorax width, (v) abdomen width.

The second set comprised 50 individuals from lemon soles and 50 from flounders. For this series the following measurements were made on each individual: (i) total length, (ii) cephalothorax length, (iii) free thorax length, (iv) abdomen length, (v) cephalothorax width, (vi) abdomen width. 
The mean values and the standard errors for these measurements are given in Tables 4 and 5. These tables show that the means for all the characters are higher for the flounder parasites than for those of the lemon soles in both series. In most, though not all, cases the differences between means for the same character differ significantly for the two types of male. The first quantitative observations had suggested the existence of marked differences between the length and width of cephalothorax and between the length of the latter and the remainder of the body in the two types. Ratios were calculated for both pairs in each series and the values, together with the standard errors, are given in Tables 6 and 7. For lemon sole parasites the mean values of both ratios are significantly higher than for any of the flounder parasites.

The major object in taking these measurements was to ascertain whether the parasites from the two host species were distinct and then to ascertain whether such a distinction, if it existed, was confined to one or shown by several characters. In particular, it was important to find out whether the parasites from different flounders resembled one another more closely than they did parasites from lemon soles.

In Tables 8 and 9 are shown the maximum differences between the mean values of the various characters for lemon sole and flounder parasites. The differences for the various measurements have been standardized to allow direct comparisons between them.

These tables show that the separation between the two parasite populations is greatest in the case of abdomen width. Cephalothorax width is also a good discriminating character in series $\mathrm{I}$, although not so good in series 2 because of the presence in it of one flounder group providing an exceptionally low mean value for this character $(0.4 \mathrm{I} 0 \mathrm{~mm})$. Good discrimination is also provided by the total length minus cephalothorax in series $\mathrm{I}$, and Table 9 shows that this difference is confined to the length of the free thorax. On the other hand, cephalothorax length does not discriminate well between the two types of parasites. It follows that good discrimination will be provided by any ratio involving abdomen width.

A useful and efficient measure of the differences between the groups of observations has been proposed by Mahalanobis (1930) and called by him the generalized distance. Not only does this quantity take into account any desired number of characters at the same time, but it also gives appropriate weight to different biological characters and takes into account the possible correlations between them (which is not done by a ratio).

If any one character is considered, the mean values for different groups may be arranged as points along a line, the distance of a point from the origin being equal to the mean for that group. The distance between two groups is then the distance between the points representing their mean values. To allow the comparison of distances for different characters all scales of measurement are equalized by dividing measurements by their standard deviations. When 
TABLE 4. ADULT MALES, SERIES 1. MEAN VALUES AND STANDARD ERRORS (MM) FOR THE DIFFERENT CHARACTERS

\begin{tabular}{|c|c|c|c|c|c|c|c|c|}
\hline Character & & $\begin{array}{c}\text { Lemon sole } \\
(47)\end{array}$ & $\begin{array}{l}\text { Flounder } \\
(50)\end{array}$ & $\begin{array}{l}\text { Flounder } \\
\text { (IO) }\end{array}$ & $\begin{array}{l}\text { Flounder } \\
\text { (I0) }\end{array}$ & $\begin{array}{l}\text { Flounder } \\
\text { (IO) }\end{array}$ & $\begin{array}{l}\text { Flounder } \\
\text { (IO) }\end{array}$ & $\begin{array}{l}\text { Flounder } \\
\text { (I0) }\end{array}$ \\
\hline \multirow[t]{2}{*}{ Total length } & Mean & $I \cdot 298$ & $I \cdot 478$ & $I \cdot 484$ & $I \cdot 490$ & I. 488 & $I \cdot 446$ & $I \cdot 430$ \\
\hline & S.E. & \pm 0.0060 & \pm 0.0058 & & & \pm 0.0130 & & \\
\hline \multirow{2}{*}{ Abdomen width } & Mean & 0.172 & 0.208 & 0.212 & $0 \cdot 208$ & 0.210 & 0.204 & 0.208 \\
\hline & S.E. & \pm 0.0011 & \pm 0.0010 & & & \pm 0.0023 & & \\
\hline \multirow[t]{2}{*}{ Cephalothorax width } & Mean & 0.376 & 0.440 & 0.442 & 0.423 & 0.426 & 0.426 & $0.44 \mathrm{I}$ \\
\hline & S.E. & \pm 0.0025 & \pm 0.0024 & & & \pm 0.0054 & & \\
\hline \multirow[t]{2}{*}{ Total length minus cephalothorax } & Mean & 0.657 & 0.801 & 0.812 & 0.820 & 0.819 & 0.800 & 0.788 \\
\hline & S.E. & $\pm 0.004 \mathrm{I}$ & \pm 0.0040 & & & \pm 0.0089 & & \\
\hline \multirow[t]{2}{*}{ Cephalothorax length } & Mean & 0.622 & 0.674 & 0.672 & 0.670 & 0.669 & 0.646 & 0.642 \\
\hline & s.e. & \pm 0.0040 & \pm 0.0038 & & & \pm 0.0086 & & \\
\hline
\end{tabular}


two or more characters are used this method of representation may be extended to two or more dimensions.

For the present data there are seven groups in series I and six in series 2 . In order to give a measure of distance between lemon sole groups the data in

TABLE 5. ADULT MALES, SERIES 2. MEAN VALUES AND STANDARD ERRORS (MM) FOR DIFFERENT CHARACTERS

\begin{tabular}{|c|c|c|c|c|c|c|c|}
\hline Character & & $\underset{(50)}{\text { Lemon sole }}$ & $\begin{array}{l}\text { Flounder } \\
\text { (IO) }\end{array}$ & $\begin{array}{l}\text { Flounder } \\
\text { (IO) }\end{array}$ & $\begin{array}{l}\text { Flounder } \\
\text { (IO) }\end{array}$ & $\begin{array}{l}\text { Flounder } \\
\text { (IO) }\end{array}$ & $\begin{array}{l}\text { Flounde } \\
\text { (IO) }\end{array}$ \\
\hline \multirow[t]{2}{*}{ Total length } & Mean & $I \cdot 302$ & $1 \cdot 503$ & $\mathrm{I} \cdot 494$ & $I \cdot 468$ & $I \cdot 440$ & I.390 \\
\hline & S.E. & \pm 0.0055 & & & \pm 0.0122 & & \\
\hline \multirow[t]{2}{*}{ Abdomen width } & Mean & 0.168 & 0.220 & 0.210 & 0.210 & 0.204 & 0.198 \\
\hline & S.E. & \pm 0.0011 & & & \pm 0.0024 & & \\
\hline \multirow{2}{*}{$\begin{array}{l}\text { Cephalothorax } \\
\text { width }\end{array}$} & Mean & 0.372 & 0.440 & $0.43^{8}$ & $\underbrace{0.432}$ & 0.435 & 0.410 \\
\hline & S.E. & \pm 0.0018 & & & $\pm 0.004 \mathrm{I}$ & & \\
\hline \multirow[t]{2}{*}{ Free thorax length } & Mean & 0.322 & 0.357 & 0.376 & $\underbrace{0.375}$ & 0.368 & 0.366 \\
\hline & S.E. & \pm 0.0024 & & & \pm 0.0054 & & \\
\hline \multirow[t]{2}{*}{ Abdomen length } & Mean & 0.352 & $0.45^{8}$ & 0.456 & $\underbrace{0.444}$ & 0.434 & 0.396 \\
\hline & S.E. & \pm 0.0027 & & & \pm 0.0059 & & \\
\hline \multirow[t]{2}{*}{$\begin{array}{l}\text { Cephalothorax } \\
\text { length }\end{array}$} & Mean & 0.627 & 0.688 & 0.662 & 0.650 & 0.639 & 0.628 \\
\hline & S.E. & \pm 0.0040 & & & \pm 0.0090 & & \\
\hline
\end{tabular}

TABLE 6. SERIES 1. MEAN RATIOS AND STANDARD ERRORS

\section{Host}

Lemon sole

Flounder ( 1 )

Flounder (2)

Flounder (3)

Flounder (4)

Flounder (5)

Flounder (6) $\underset{\text { size }}{\text { Sample }}$

47

50

IO

Io

IO

IO

I0
Cephalothorax length

Cephalothorax width

$$
\begin{aligned}
& \text { I. } 65 \pm 0.011 \\
& I .54 \pm 0.011 \\
& I .52 \pm 0.022 \\
& I .59 \pm 0.040 \\
& I .57 \pm 0.011 \\
& I .52 \pm 0.020 \\
& I .46 \pm 0.018
\end{aligned}
$$

Cephalothorax length

Total length minus cephalothorax

TABLE 7. SERIES 2. MEAN RATIOS AND STANDARD ERRORS

Host

Lemon sole

Flounder (I)

Flounder (2)

Flounder (3)

Flounder (4)

Flounder (5)

\section{Sample \\ size \\ Cephalothorax length \\ Cephalothorax width}

50

IO

IO

Io

IO

Io

$$
\begin{aligned}
& I \cdot 68 \pm 0.012 \\
& I \cdot 57 \pm 0.028 \\
& I \cdot 51 \pm 0.023 \\
& I \cdot 50 \pm 0.014 \\
& I \cdot 47 \pm 0.013 \\
& I .54 \pm 0.029
\end{aligned}
$$

Cephalothorax length

Total length minus cephalothorax
$0.93 \pm 0.007$

$0.85 \pm 0.023$

$0.80 \pm 0.012$

$0.79 \pm 0.007$

$0.80+0.01$

$0.82 \pm 0.01 \mathrm{I}$ 
TABLE 8. SERIES 1. DIFFERENCES BETWEEN STANDARDIZED MEAN VALUES FOR DIFFERENT CHARACTERS

Maximum difference between flounder

Character

Abdomen width

Cephalothorax width

Total length minus cephalothorax

Cephalothorax length
Minimum difference between flounder and lemon sole parasites

$\begin{array}{lr}\mathbf{I} \cdot 08 & 4.33 \\ \mathbf{I} \cdot 12 & 2.76 \\ \mathrm{I} \cdot 15 & 4.03 \\ \mathrm{I} \cdot \mathrm{I} 8 & 0.73\end{array}$

TABLE 9. SERIES 2. DIFFERENCES BETWEEN STANDARDIZED MEAN VALUES FOR DIFFERENT CHARACTERS

$\begin{array}{lcc}\text { Character } & \begin{array}{c}\text { Maximum difference } \\ \text { between flounder } \\ \text { parasites }\end{array} & \begin{array}{c}\text { Minimum difference } \\ \text { between flounder } \\ \text { and lemon sole } \\ \text { parasites }\end{array} \\ \text { Abdomen width } & 2 \cdot 90 & 3.94 \\ \text { Cephalothorax width } & 2 \cdot 31 & 2.92 \\ \text { Free thorax length } & 1 \cdot 11 & 2.05 \\ \text { Abdomen length } & 3.30 & 2.34 \\ \text { Cephalothorax length } & 2.12 & 0.03\end{array}$

TABLE 10. DISTANCES BETWEEN GROUPS BASED ON CEPHALOTHORAX LENGTH, LENGTH OF REST OF BODY AND CEPHALOTHORAX WIDTH (In arbitrary units)

\begin{tabular}{|c|c|c|c|c|c|c|c|c|c|c|c|c|c|}
\hline \multicolumn{2}{|c|}{$(\mathrm{LS}) \mathrm{I}$} & \multicolumn{2}{|c|}{$(\mathrm{LS}) 2$} & \multicolumn{2}{|c|}{$F_{\text {II }}$} & \multicolumn{2}{|c|}{$\mathrm{F}_{12}$} & \multicolumn{2}{|c|}{$\mathrm{F}_{13}$} & \multicolumn{2}{|c|}{$\mathrm{F}_{14}$} & \multicolumn{2}{|c|}{ FI5 } \\
\hline$(\mathrm{LS})_{2}$ & 0.7 & $(\mathrm{LS}) \mathrm{I}$ & 0.7 & $(\mathrm{LS}) \mathrm{I}$ & $5 \cdot 3$ & $(\mathrm{LS})_{\mathrm{I}}$ & $5 \cdot 8$ & $(\mathrm{LS})_{\mathrm{I}}$ & 5.0 & $(\mathrm{LS}) \mathrm{I}$ & $5 \cdot 2$ & $(\mathrm{LS}) \mathrm{I}$ & 4.5 \\
\hline FII & $5 \cdot 3$ & FII & 5.9 & $(\mathrm{LS}) 2$ & 5.9 & $(\mathrm{LS})_{2}$ & $6 \cdot 2$ & $(\mathrm{LS}) 2$ & 5.5 & $(\mathrm{LS}) 2$ & 5.7 & (LS) 2 & $5 \cdot 1$ \\
\hline$F_{12}$ & 5.8 & $\mathrm{~F}_{12}$ & $6 \cdot 2$ & $\mathrm{~F}_{\mathrm{I} 2}$ & 0.4 & $F_{\text {II }}$ & 0.4 & $F_{I I}$ & $I \cdot 2$ & FII & $I \cdot I$ & $F_{\text {II }}$ & $I \cdot 2$ \\
\hline $\mathrm{Fr}_{3}$ & 5.0 & FI3 & $5 \cdot 5$ & $\mathrm{FI}_{3}$ & $I \cdot 2$ & $\mathrm{~F}_{13}$ & $\mathrm{I} \cdot 3$ & $F_{12}$ & $I \cdot 3$ & $\mathrm{~F}_{12}$ & $I \cdot I$ & $\mathrm{~F}_{12}$ & I. 4 \\
\hline $\mathrm{F}_{\mathrm{I} 4}$ & $5 \cdot 2$ & $\mathrm{~F}_{\mathrm{I} 4}$ & 5.7 & $\mathrm{~F}_{\mathrm{I} 4}$ & $I \cdot I$ & $\mathrm{FI}_{4}$ & $I \cdot I$ & $\mathrm{~F}_{14}$ & 0.3 & $\mathrm{~F}_{\mathrm{I}_{3}}$ & 0.3 & $\mathrm{~F}_{13}$ & $I \cdot 2$ \\
\hline F I 5 & 4.5 & FI 5 & $5 \cdot 1$ & FI5 & $I \cdot 2$ & FI5 & I. 4 & FI5 & $I \cdot 2$ & FI5 & $I \cdot 2$ & FI4 & $I \cdot 2$ \\
\hline FI6 & $5 \cdot 4$ & FI6 & 6.0 & FI6 & $I \cdot 2$ & FI6 & $I \cdot I$ & FI6 & $\mathrm{I} \cdot \overline{8}$ & FI6 & I. 7 & FI6 & 0.9 \\
\hline $\mathrm{F}_{2 \mathrm{I}}$ & 6.6 & $F_{2 I}$ & $7 \cdot 2$ & $F_{2 I}$ & I. 8 & $F_{2 I}$ & I. 5 & $F_{2 I}$ & I. 7 & $F_{2 I}$ & I. 5 & $F_{21}$ & 2.5 \\
\hline$F_{22}$ & $5 \cdot 4$ & $\mathrm{~F}_{22}$ & 6.0 & $\mathrm{~F}_{22}$ & 0.5 & $F_{22}$ & 0.4 & $F_{22}$ & $I \cdot I$ & $\mathrm{~F}_{22}$ & $I \cdot 0$ & $F_{22}$ & $I \cdot 0$ \\
\hline$F_{23}$ & $5 \cdot 3$ & $\mathrm{~F}_{23}$ & 5.9 & $\mathrm{~F}_{23}$ & I. O & $\mathrm{F}_{23}$ & $I \cdot O$ & $\mathrm{~F}_{23}$ & $I \cdot I$ & $\mathrm{~F}_{23}$ & 0.9 & $\mathrm{~F}_{23}$ & 0.8 \\
\hline $\mathrm{F}_{24}$ & 4.8 & $\mathrm{~F}_{24}$ & 4.8 & $\mathrm{~F}_{24}$ & I. 3 & $\mathrm{~F}_{24}$ & I. 4 & $\mathrm{~F}_{24}$ & I. 4 & $\mathrm{~F}_{24}$ & I. 7 & $\mathrm{~F}_{24}$ & 0.8 \\
\hline$F_{25}$ & 3.5 & $F_{25}$ & 3.5 & $F_{25}$ & $2 \cdot 3$ & $F_{25}$ & $2 \cdot 6$ & $F_{25}$ & I.9 & $\mathrm{F}_{25}$ & 2.0 & $F_{25}$ & $I \cdot 2$ \\
\hline
\end{tabular}

\begin{tabular}{|c|c|c|c|c|c|c|c|c|c|c|c|}
\hline \multicolumn{2}{|c|}{ FI6 } & \multicolumn{2}{|c|}{$F_{2 I}$} & \multicolumn{2}{|c|}{$F_{22}$} & \multicolumn{2}{|c|}{$\mathrm{F}_{23}$} & \multicolumn{2}{|c|}{$\mathrm{F}_{24}$} & \multicolumn{2}{|c|}{$\mathrm{F}_{25}$} \\
\hline 8) & & S) I & 6. & S) I & $5 \cdot 4$ & LS) I & $5^{\circ}$ & $(\mathrm{LS}) \mathrm{I}$ & 4.8 & LS) I & \\
\hline 5) & & $(\mathrm{LS}) 2$ & 7 & $(\mathrm{LS}) 2$ & 0. & $(\mathrm{LS}) 2$ & 5 & (LS) 2 & 5 & LS) 2 & \\
\hline FII & $I \cdot 2$ & $F_{\text {II }}$ & I. 8 & $F_{I I}$ & 0.5 & $F_{I I}$ & I. O & $F_{I I}$ & $\mathrm{I} \cdot 3$ & FII & \\
\hline $\mathrm{F}_{12}$ & $I \cdot I$ & $\mathrm{~F}_{12}$ & I. 5 & $\mathrm{~F}_{12}$ & 0.4 & $\mathrm{~F}_{12}$ & $I^{\circ}$ & $\mathrm{F}_{12}$ & I. & $\mathrm{F}_{12}$ & \\
\hline $\mathrm{F}_{13}$ & I. 8 & 13 & I. & 13 & $I \cdot$ & $F_{13}$ & $I \cdot$ & $F_{13}$ & I. & $\mathrm{F}_{13}$ & \\
\hline FI4 & I. 7 & 14 & I. 5 & 4 & $I \cdot O$ & & 0. & 4 & I. & I4 & \\
\hline FI5 & 0.9 & 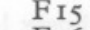 & 2. & 5 & I.O & FI5 & 0. & 5 & 0. & F I 5 & I. \\
\hline $\mathrm{F}_{2 \mathrm{I}}$ & $2 \cdot 4$ & 16 & $2 \cdot 4$ & 76 & I. 8 & FI6 & 0.8 & FI6 & 0. & FI6 & 2 \\
\hline $\mathrm{F}_{22}$ & 0.8 & $\mathrm{~F}_{22}$ & I. 7 & $\mathrm{~F}_{21}$ & I. 7 & $\mathrm{~F}_{2 \mathrm{I}}$ & I. 9 & F2I & $2 \cdot 8$ & $\mathrm{~F}_{2 \mathrm{I}}$ & 3 \\
\hline$F_{23}$ & 0.8 & $\mathrm{~F}_{23}$ & $I \cdot C$ & $\mathrm{~F}_{23}$ & 0.6 & $F_{22}$ & 0.6 & $\mathrm{~F}_{22}$ & $I \cdot I$ & $F_{22}$ & \\
\hline F 24 & 0.6 & 24 & $2 \cdot 8$ & $F_{24}$ & $I \cdot I$ & $\mathrm{~F}_{24}$ & $I \cdot C$ & $\mathrm{~F}_{23}$ & I. & $F_{23}$ & I \\
\hline F25 & $2 \cdot I$ & F 25 & 3.5 & $F_{25}$ & $2 \cdot 2$ & $\mathrm{~F}_{25}$ & I. 8 & F 25 & I. 8 & $\mathrm{~F}_{24}$ & \\
\hline
\end{tabular}

LS, lemon sole; F, flounder; I2, denotes the second flounder of the first series, etc. 
series I and 2 were combined in respect of cephalothorax length, cephalothorax width and the length of the rest of the body and the generalized distances (shown in Table ro) were calculated.

Clearly the points for the parasites of the lemon soles lie very close together and relatively quite far away from the nearest point of the flounder parasites. The shortest distance between the lemon sole parasites and those of the flounder is 3.5 , equal to the distance between the two flounder parasite populations farthest apart. The average distance between flounder groups is $\mathrm{I} \cdot 4$.

Having shown that it is quite reasonable to consider the parasites of the flounders as being distinct from those of the lemon sole, it is of interest to find the character or combination of characters which most clearly brings out the difference between the two groups of parasites. To do this, the data from series 2 only were used and the measurements from the parasites of individual flounders combined into a single set. Analysis showed that all characters are useful for the purpose of discrimination, but the additional information in this respect given by cephalothorax length was relatively small. Using all characters, the combination which most clearly brings out the differences between the two groups was found to be

$$
\text { (A.W.) }+0.400 \text { (C.W.) }+0.376 \text { (F.T.L.) }+0.177 \text { (A.L.) }-0.145 \text { (C.L.), }
$$

where A.L. is abdomen length, A.W. abdomen width, F.T.L. free thorax length, C.L. cephalothorax length and C.W. cephalothorax width.

This combination is known as a discriminant function (Fisher, 1936). The mean value of this quantity for the lemon sole parasites of series 2 is 27.358 and for the flounder parasites is 33.468 . The difference 6.1 Io has a standard error of $\pm 0.22 \mathrm{I}$ and is therefore highly significant. In fact, using this function of the characters to classify an individual parasite of unknown origin, the probability of misclassification is about three in a thousand.

\section{MODE OF ATTACHMENT}

The specific name of $L$. branchialis refers to the mode of attachment of this parasite. It is described by Linnaeus ( 1767 ) as being located 'ad branchias'. Stekhoven (1936) doubts the fitness of the name and regards the species as a heart rather than a gill parasite. His histological examinations have revealed that the bulbus arteriosus is the main region of penetration by this parasite. In his later work (Stekhoven \& Punt, I937), however, he modifies his opinion and states that the parasite is very often found in other localities. This applies, according to him, primarily to the older hosts. The distance from the point of attachment to the bulbus becomes too great and the parasite is no longer capable of reaching it.

The following observations were made during the present investigations:

(I) Small whiting had the parasite implanted in the bulbus in the majority 
of cases (over $75 \%$ ). One parasite penetrated the ventricle, the walls of which were pushed out by the antlers.

(2) Out of 295 of the mature female parasites from haddock only 19 were attached to the bulbus arteriosus $(6 \cdot 4 \%)$, while the remaining ones penetrated mainly the ventral aorta and some were attached to the branchial arteries.

(3) In Icelandic cod 8 out of 25 parasites were found in the bulbus arteriosus $(33.3 \%)$. Here also one parasite was embedded in the ventricle.

When the above facts are considered, two things become clear:

(a) The percentage of parasites in the bulbus is far larger both for whiting and cod than for haddock.

(b) This difference is not due to environmental conditions. Both whiting and cod are infested at an early age, while haddock continues to be infested throughout its life.

Parasites which infest a larger host might be unable to penetrate the bulbus due to the distances involved. But it must be remembered that at least a half of the infested haddock become infested during the first two years of their lives. Even some of the old haddock bear mature parasites, with the necks almost as long as the rest of their bodies and fully capable of reaching into the bulbus area. Sometimes a parasite penetrates from one subopercular cavity into the other, so that its neck is twice the length necessary to reach the bulbus.

Reference to Fig. 6 shows that there is no great difference in the spatial relations between the main area of attachment of Lernaeocera and the cardiac region of whiting and haddock. It would appear that in whiting the parasite may even have to reach farther back to enter the bulbus than in the haddock; and, indeed, Lernaeocera infesting whiting are very often found in the bulbus even when it does not represent the most accessible spot. Fig. 5 shows that in whiting the neck of Lernaeocera is often bent at a right angle to the main axis of the body. Being attached at the same level as the heart it has to make a sharp bend in order to reach it. This phenomenon is almost suggestive of a tropism and, in fact, the term 'arterotropism' has been coined for it by Capart (1948).

The haddock Lernaeocera, generally with the same possibilities of reaching the heart, is usually implanted more anteriorly in the ventral aorta, although this frequently means that the neck has to travel a longer way. This results in a striking difference between the two parasites. The whiting parasite has a short neck bent at a right angle to the longitudinal axis of the body, and that of the haddock has a relatively longer neck which deviates only slightly from that axis.

\section{THE SEPARATION OF THE SPECIES}

In the preceding sections of this paper several definite and consistent differences between Lernaeocera infesting whiting and cod and Lernaeocera found on haddock were discussed. The differences were of such character and extent 
that they could only be explained by the existence of specific distinctions between these two parasites.

We have seen that the geographic distribution of the incidence of Lernaeocera in haddock differs greatly from that of cod and whiting. First, haddock is infested throughout the northern North Sea, while the other two hosts are are free from infestation in the open sea. Secondly, no infested haddock is found outside the European continental shelf, while cod of, for example,
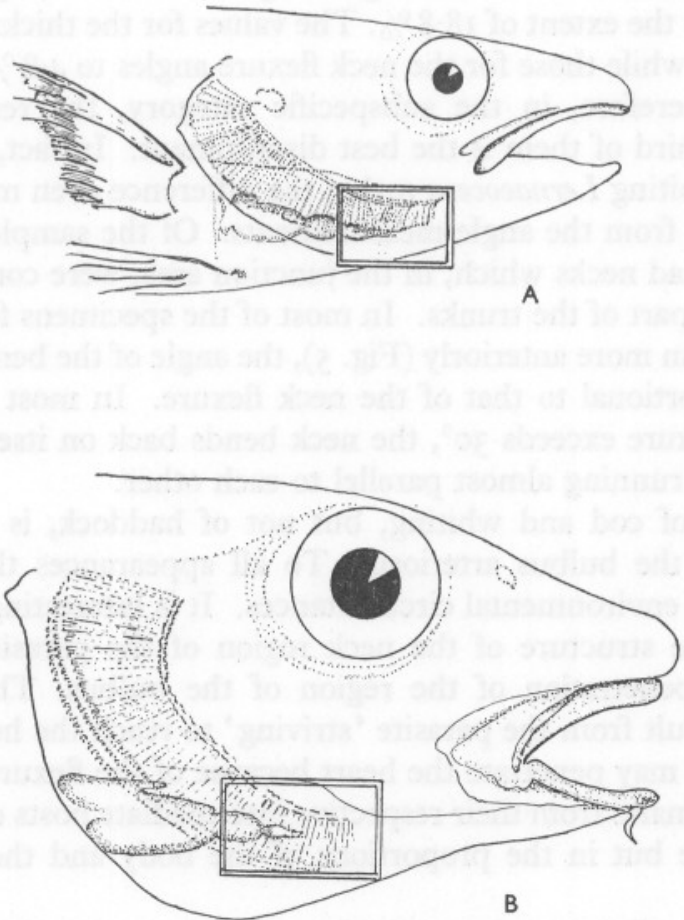

Fig. 6. Heads of (A) whiting and (B) haddock, showing the main attachment area of Lernaeocera and its relation to the position of the heart.

Faröe and Iceland are infested to the same, or larger, extent than in the North Sea. One can visualize the spread of Lernaeocera from the North Sea northwards. Infested cod carry over the mature parasites to Faröe, the eggs deposited there hatch and, in the presence of a suitable intermediate host (both lemon sole and flounder are present in that area), the parasite becomes established. Haddock, presumably owing to its inability to negotiate the deep water barriers, does not spread its own Lernaeocera. Only the specific distinctness of the parasite of whiting and cod can explain the absence of infestation in haddock outside the European continental shelf.

The three most important differences in the morphology of the two types 
of Lernaeocera were (i) the angles of the genital flexure, (ii) the relation between the ratios of thickness of the neck to that of the trunk, and (iii) the structural differences of the neck and trunk junction area.

Ginsburg (1938), proposing his definition of the arithmetical concept of species, subspecies and race, gives certain values for 'intergradation' of a particular character under comparison. These values are: 10 \% or less for specific difference, $15-25 \%$ for a subspecific one and $30-40 \%$ for a racial one. Comparison of the values for the angles of genital flexure (Fig. 3) shows them to intergrade to the extent of $18 \cdot 8 \%$. The values for the thickness ratios intergrade to $10 \%$, while those for the neck flexure angles to $4.8 \%$ only. The first of them is, therefore, in the subspecific category, the remaining two in specific. The third of them is the best discriminant. In fact, the presence of the bulge in whiting Lernaeocera makes the difference even more pronounced than it appears from the angle measurements. Of the sample of 58 parasites of whiting 13 had necks which, in the junction area, were completely parallel to the anterior part of the trunks. In most of the specimens from whiting the neck bends again more anteriorly (Fig. 5), the angle of the bend being roughly inversely proportional to that of the neck flexure. In most of the parasites whose neck flexure exceeds $30^{\circ}$, the neck bends back on itself, its distal and proximal parts running almost parallel to each other.

Lernaeocera of cod and whiting, but not of haddock, is embedded predominantly in the bulbus arteriosus. To all appearances this difference is independent of environmental circumstances. It is interesting to speculate to what extent the structure of the neck region of the parasite of whiting is related to its penetration of the region of the bulbus. The characteristic flexure may result from the parasite 'striving' to reach the heart of the host; alternatively, it may penetrate the heart because of the flexure of the neck.

The mature males from their respective intermediate hosts differed not only in absolute size but in the proportions of the body and the extent of pigmentation.

Summing up all these points of difference, the author became convinced that the two parasites are specifically distinct. The existence of some distinguishing features between the two types of Lernaeocera has, however, been observed as early as the eighteenth century. O. Fabricius (I780, p. 336) and O. F. Müller (I789, p. 65) both regarded the parasite of the haddock as 'varietas minor' of Lernaea gadina (= Lernaeocera branchialis), but it appears that size was the only difference prompting these two authors to regard this parasite as distinct from those of 'Gadi barbati'. The figure which O. F. Müller gives of his L. gadina (pl. cxviII, fig. 4) is evidently that of the cod and whiting Lernaeocera.

The discovery that the name $L$. branchialis is at present used to cover two distinct, if very similar, species brings with it the problem of which of the two species should retain the old name and which should be given a new one. 
The solution of this problem depends on the host species from which $L$. branchialis was first described. Linnaeus ( 1767$)$, who first named the animal in the 12th edition of Systema Naturae (p. 1092), describes it as parasitizing: 'Gadis, ad branchias.' Possibly Linnaeus never actually saw the animal and details of it must be sought in Strøm (1762), to whom Linnaeus refers. Strøm is rather vague about the hosts on which the parasite occurs, stating that it is found 'i Fiskenes Tokn' (on gills of fishes). He adds later, however, 'besonderlig i Torskenes om Foraaret' (especially on cod in the spring). In view of this statement, which is the oldest on record concerning the host of L. branchialis, it seems proper to retain the old name for the parasite of whiting and cod and rename the parasite of haddock, which the author proposes to name L. obtusa n.sp. The name is suggestive of the characteristic wide angle of genital flexure.

\section{Lernaeocera obtusa sp.nov.}

Lernaea gadina (in part) Fabricius, I780. (The reference to 'varietas minor', judging from its context, does not constitute a proposal of 'minor' as a name for Lernaeocera found on haddock.)

Lernaea gadina (in part) O. F. Müller, I789. (The reference to 'varietas minor' as above.)

Lernaeocera branchialis (in part) Blainville, I822. (A figure of L. obtusa is given, but Linnaeus 1767 , following Strøm 1762 , by not mentioning the haddock has implicitly restricted $L$. branchialis to the parasite of the cod.)

Lernaea branchialis (in part) T. \& A. Scott, I913.

Lernaeocera branchialis (in part) Oorde de Lint \& Stekhoven, 1936.

Holotype: mature female deposited in British Museum (B.M. no. 1957. 2.21.I). Paratypes: six mature males and females deposited in British Museum (N.H.) B.M. no. I957.2.21.2. Six mature males and females deposited in Royal Scottish Museum, Edinburgh, No. Royal Scottish Museum 1957.24. Type locality: Northern North Sea. Collected by Z. Kabata.

Description. Female: size within the range of that of L. branchialis. Shape generally similar to that of $L$. branchialis, with the following exceptions: (I) The flexure of the neck and the anterior part of the trunk forms roughly a right angle (average of 58 specimens was $93^{\circ}$, with the range of $58-142^{\circ}$ ), while that of $L$. branchialis forms an acute angle or no angle at all, both parts running parallel to each other. (2) The neck is considerably thicker in relation to the diameter of the trunk than in L. branchialis. (3) The flexure of the genital segment forms usually an obtuse angle (average of 65 specimens was $99^{\circ}$ ), while that of $L$. branchialis forms an acute one.

Male: generally similar to the male of $L$. branchialis, but mean size $\mathrm{I} \cdot 30 \mathrm{~mm}$ as compared with $\mathrm{I} \cdot 46$ of the latter. Cephalothorax longer in relation to the body length than in L. branchialis. Cephalothorax and abdomen narrower than in the latter species. 
Intermediate host: lemon sole, Microstomus kitt (Walbaum); habitat: gills. Final host (female only): haddock, Gadus aeglefinus L.; habitat: branchial chamber or gills.

The author wishes to express his gratitude to the following members of the staff of the Marine Laboratory, Aberdeen: Mr J. A. Pope, who is responsible for the statistical analysis and largely for the form of the section on the morphology of the male, Dr B. B. Rae and Dr J. H. Fraser for their interest, encouragement, useful criticism and corrections of the manuscript.

Thanks are also due to Dr P. A. Orkin of the University of Aberdeen for reading the manuscript and for help in tracing literature, to $\mathrm{Mr} \mathrm{C}$. Muir, who drew Fig. 5, and to Dr D. W. Tucker of the British Museum for access to Fabricius's Fauna Groenlandica.

\section{SUMMARY}

The fishes harbouring parasites of the genus Lernaeocera can be divided, according to the presence or absence of contact with the coastal waters, into 'inshore' and 'offshore' groups. According to literature, only L. branchialis occurs commonly on hosts in both groups. The difference between this and the remaining species of the genus is explained by the existence of two different species covered by the name L. branchialis. One of these species is parasitic on cod and whiting, the other on haddock. The two species have also different intermediate hosts (flounder and lemon sole respectively) and differ in morphology of the adult male and female and in the mode of attachment to the final host.

Lernaeocera of whiting and cod is distributed mainly in the coastal area, while that from haddock extends over the whole of the North Sea. The former, but not the latter, is present outside the European continental shelf. All these differences lead to the conclusion that the two types represent two different species. The old name is retained for the parasite of cod and whiting. The parasite of haddock is the new species, to which the name Lernaeocera obtusa is given.

\section{REFERENCES}

BASSET-SMith, P. W., I896. Notes on the parasitic copepoda of fish obtained at Plymouth, with descriptions of new species. Ann. Mag. nat. Hist., Vol. 18, pp. 8-16.

Blainville, H. M. D. de, I822. Mémoire sur les Lernées (Lernaea, Linn.). F. Phys. Chim. Hist. nat., T. 95, pp. 372-80 and 437-47.

CAPART, A., 1948. Le Lernaeocera branchialis (Linné 1767). Cellule, Vol. 52, pp. 159212.

Dollfus, R. P., I953. Parasites Animaux de la Morue Atlanto-Arctique. Encycl. biol., Vol. 43, pp. 350-63.

FABRICIUS, O., I780. Fauna Groenlandica. 452 pp. Hafniae et Lipsiae. 
FISHER, R. A., 1936. The use of multiple measurements in taxonomic problems. Ann. Eugen., Lond., Vol. 8, pp. 179-88.

GinsBURG, J., 1938. Arithmetical definition of the species, subspecies and race concept with a proposal for modified nomenclature. Zoologica, N.Y., Vol. 23 (13), p. 253.

GouIllart, M., 1937. Recherches sur les Copépodes parasites. Trav. Sta. zool. Wimereux, T. 12, pp. 309-457.

GüNTHER, A., 1862. Catalogue of the Acanthopterygii Pharyngognathi and Anacanthini in the collection of the British Museum. Vol. 4, 534 pp. London: British Museum.

KRøYER, H., I863. Bidrag til Kundsgab om Snyltekrebsene. Naturh. Tidsskr., Bd. 2, pp. 74-426.

LinNaEus, C., I767. Systema Naturae, I2th Ed.

Mahalanobis, P. C., I930. On tests and measures of group divergences. F. Asiat. Soc. Beng., Vol. 26, pp. 54I-88.

MÜLLER, O. F., I789. Zoologia Danica, Vol. 3.

Oorde De Lint, G. M. van \& Schuurmans Stekhoven, J. H., I936. Copepoda parasitica. Tierw. N.-v. Ostsee, Teil Ioc, pp. 73-198 (Lief. 3I).

Quidor, A., I912. Copepodes Parasites. Deuxième Expédition Antarctique Française (1908-1910), Paris, pp. 197-215.

RAE, B. B., 1939. Factors in the growth of lemon soles. Sci. Invest. Fish. Scot., I939, No. 3,18 pp.

Scott, A., I90I. Lepeophtheirus and Lernaea. L.M.B.C. Memoir, No. 6.

Scott, T., I900. Notes on some crustacean parasites of fishes. Rep. Fish. Bd Scot., No. 18, pp. 144-88.

Scott, T. \& ScotT, A., I913. British Parasitic Copepoda. London: Ray Society.

Shulman, S. S. \& Shulman-Albova, R. E., 1953. Parasites of Fishes of the White Sea. 192 pp. Acad. Sci. U.R.S.S. Moscow. [In Russian.]

Sproston, N. G., I94I. The developmental stages of Lernaeocera branchialis. F. mar. biol. Ass. U.K., Vol. 25, pp. 44I-66.

Sproston, N. G. \& Hartley, P. H. T., I94I. The ecology of some parasitic copepods of gadoids and other fishes. F. mar. biol. Ass. U.K., Vol. 25, pp. 36I-92.

Stekhoven, J. H. SchuURmans, I935. Copepoda parasitica from the Belgian coast. Bull. Mus. Hist. nat. Belg., T. II, No. 7, 13 pp.

— 1936. Beobachtungen zur Morphologie und Physiologie der Lernaeocera branchialis L. und Lernaeocera lusci Basset-Smith. Z. Parasitenk., Bd. 8, pp. 659-96.

Stekhoven, J. H. Schuurmans \& Punt, A., I937. Weitere Beiträge zur Morphologie und Physiologie der Lernaeocera branchialis L. Z. Parasitenk., Bd. 9, pp. 648.

Strøм, H., 1762. Physisk og Oeconomisk Beskrivelse over Fogderiet Sondmør, beliggende $i$ Bergens Stift $i$ Norge. Første Part. Copenhagen.

Templeman, W., I953. Knowledge of division of stocks of cod, haddock, redfish and American plaice in subareas 3 and 2 of the Northwest Atlantic Convention area. Ann. Proc. int. Comm. N.W. Atlant. Fish., Vol. 3, pp. 63-5.

Thомson, G. N., 1889. Parasitic Copepoda of New Zealand. Trans. Proc. N.Z. Inst., Vol. 22, pp. 353-75.

WILSON, C. B., I9I7. North American parasitic copepods belonging to the Lernaeidae: with a revision of the entire family. Proc. U.S. nat. Mus., Vol. 53, pp. I-I50. 


\section{Note added in proof}

Since this paper was written, another interesting fact has been brought to light. Investigations in Faröe waters revealed Lernaeocera on the gills of the lemon sole. No other flatfish species has yet been found to carry this parasite in that area. The biometric measurements of the adult males found on the lemon sole in Faröe wateres proved them to resemble those of the lemon soles of the North Sea.

A suggestion has been put forward in this paper (p. 573) as to the possible way in which L. branchialis spread northwards from the North Sea. It is only larger and older cod which can be regarded as possible carriers of the parasite across the deep water barrier which confines the host of L. obtusa within the limits of the continental shelf. Such cod, crossing to Faröes, are unlikely to enter the littoral zone and come in contact with the flounder. The parasite will therefore deposit its eggs in deeper waters and its copepodids, to survive, must become adapted to a host available in those waters. The lemon sole, as the most common local flatfish species, became an intermediate host. The fact that, in spite of the infestation of the lemon sole, no parasite is found on the haddock, strongly suggests that the larvae on that flatfish belong to L. branchialis.

The biometric similarity between the parasites found on the lemon soles in Faröes and the North Sea suggests that the bodily proportions of the male are subject to environmental influences and cannot be used as specific discriminant. The conclusions of the section of this paper dealing with the morphology of the male appear therefore to be incorrect.

While not affecting the main argument of this paper, the discovery focuses attention on the interesting and little-known problems of ecology of marine parasites. 